\title{
Infections with Digenean Trematode Metacercariae in Two Invasive Alien Fish, Micropterus salmoides and Lepomis macrochirus, in Two Rivers in Chungcheongbuk-do, Republic of Korea
}

\author{
Seongjun Choe, Hansol Park, Dongmin Lee, Yeseul Kang, Hyeong-Kyu Jeon, Keeseon S. Eom* \\ Department of Parasitology, Medical Research Institute and Parasite Resource Bank, School of Medicine, Chungbuk National University, \\ Cheongju 28644, Korea
}

\begin{abstract}
Present study was performed to survey infection status of digenetic trematode metacercariae in 2 alien fish species, Micropterus salmoides (largemouth bass) and Lepomis macrochirus (bluegill), in 2 rivers draining Chungcheongbuk-do, Republic of Korea. A total of 107 largemouth bass and 244 bluegills were caught in Daecheong-ho (ho=lake) and Musim-cheon (a branch of Geum-gang), in Chungcheongbuk-do April-July 2015. Additionally, 68 native fish of 5 species, i.e., Zacco platypus, Hemibarbus longirostris, Carassius auratus, Pseudogobio esocinus and Puntungia herzi, were caught from the same water bodies. All of the fish collected were examined by artificial digestion method. The metacercariae of Centrocestus armatus, Clinostomum complanatum, Metagonimus sp. and Diplostomum spp. were detected from 4 out of 5 native fish species in Daecheong-ho. However, any metacercariae were not found from $87 \mathrm{M}$. salmoides and 177 L. macrochirus in Daecheong-ho. In Musim-cheon, metacercariae of Exorchis oviformis and Metacercaria hasegawai were detected from $78 \%$ Z. platypus and 34\% L. macrochirus, but any metacercariae not found in M. salmoides. We report here that the 2 alien fish species were less infected with the metacercariae than the native ones. Surveys on the metacercariae in the alien fish species in geographically various rivers should be undertaken for better understanding on the role of alien fish species in the trematode infections in Republic of Korea.
\end{abstract}

Key words: Metacercariae, Micropterus salmoides, Lepomis macrochirus, alien fish, Geum river

Freshwater fish have been recognized as the main source of trematode infections in the Republic of Korea. Although other kinds of factors can also act as an infection source of zoonotic parasites, freshwater fish are considered comparatively more important than other factors [1]. Thus the prevalence of fishborne zoonotic helminthes has been endemically maintained in Korea whereas that of soil-transmitted helminthes has been dramatically decreased [2-4]. A recent survey showed a higher prevalence of fish-born trematodes, i.e., Clonorchis sinensis and Metagonimus spp. (8.4\% and $1.0 \%$, respectively), than soiltransmitted helminthes such as Ascaris lumbricoides and Trichuris trichiura ( $0.01 \%$ and $0.1 \%$, respectively) in residents along 5 major rivers in Korea [5]. On the other hand, many Korean

- Received 10 April 2018, revised 3 October 2018, accepted 10 October 2018.

*Corresponding author (kseom@chungbuk.ac.kr)

(c) 2018, Korean Society for Parasitology and Tropical Medicine

This is an Open Access article distributed under the terms of the Creative Commons Attribution Non-Commercial License (http://creativecommons.org/licenses/by-nc/4.0) which permits unrestricted non-commercial use, distribution, and reproduction in any

medium, provided the original work is properly cited. researchers have surveyed the infection status of digenetic trematode metacercariae (DTM) in freshwater fishes from various localities to evaluate the endemicity of subjected trematodes in the surveyed areas [6-12]. Especially, lots of studies were conducted for one of the most important zoonotic parasites, C. sinensis in Korea. Kim et al. [6]. investigated 34 localities including the Geum-gang (gang=river) basin, which was similar region with the present study for understanding the infection status of $C$. sinensis metacercariae (CsMc) using 21 species of fishes. Connectively, Cho et al. [7] surveyed 3 latitudinal regions of Korean Peninsula in 2008, and later Cho et al. [8], also investigated the infection status of DTM in 32 freshwater fish species $(\mathrm{n}=865)$ from Gangwon-do (do=province). Additionally, Sohn et al. [9-11] performed some epidemiological works on the infection status of DTM in freshwater fish from some rivers, i.e., Imjin-gang, Hantan-gang, Seomgjingang, Wi-cheon (cheon=stream) and Tamjin-gang [12] in Korea. Although many studies focused on native freshwater fishes, parasites of invasive alien species are poorly known in Ko- 
rea. Two invasive alien fish species, namely, the largemouth bass Micropterus salmoides and the bluegill Lepomis macrochirus, were introduced to Korea from the U.S.A. as a food resource and for economic reasons. However, the business failed and they were released or escaped from fish farms. The alien fishes are now distributed widely throughout the Korean ecosystem due to their rapid growth, high reproduction rate, predatory instinct against native species, and the almost complete absence of an enemy [13-15]. They currently seem to have adapted successfully to the Korean environment and are occasionally eaten by humans in addition to the native fishes. It appears that parasitic helminthes of alien fish species are poorly investigated until present study in Korea. The aims of the present study were to investigate the parasitic helminthes of 2 invasive alien fish species in Korea, intensively, and to compare their infection status with that of native fishes.

A total of 107 largemouth bass (155-477 mm in length and 65$1,360 \mathrm{~g}$ in weight) and 244 bluegills (80-180 $\mathrm{mm}$ in length and $16-71 \mathrm{~g}$ in weight) were purchased from a local fisherman and/or caught by the lure-fishing in the upper stream region of Daecheong-ho (ho=lake) in Hoenam-myeon (myeon=township), Boeun-gun, and the upper stream region of Musim-cheon in Jangam-dong (dong=village), Cheongiu-si (si=city), Chungcheongbuk-do (do= province) from April to July 2015. Additionally, total 68 native fishes in 5 species $(\mathrm{n}=69)$, i.e., Zacco platypus (49), Hemibarbus longirostris (5), Carassius auratus (8), Pseudogobio esoci- nus (3) and Puntungia herzi (3), were also collected in the same regions (Table 1). The fishes were measured and then careful observations were made of the body surface and fins with the naked eye to find large-sized metacercariae. Eye balls were separated from the body and observed under a stereomicroscope for detecting diplostomid metacercariae. All body contents including gills and internal organs were then blended and digested by an artificial digestion method using pepsin and $\mathrm{HCl}$ [1] for the detection of metacercariae and other larval parasites. These procedures were conducted individually on each fish. The identifications of DTM detected were done with the aid of the differential keys in Sohn [1].

Despite the small numbers of native fishes examined, 4 species of trematode metacercariae, namely, Centrocestus armatus, Clinostomum complanatum, Metagonimus sp. and diplostomula, were detected from 4 native fish species, Zacco platypus, Hemibarbus longirostris, Carassius auratus and Pseudogobio esocinus, in the Daecheong-ho region. Metacercariae of $C$. armatus were only found from Z $\mathrm{Z}$. platypus with a prevalence as high as $87 \%$ (27 of 31 fishes). Diplostomula was detected from the eye balls of 8 Z. platypus (26\%), 5 H. longirostris (100\%), 4 C. auratus (50\%) and 1 P. esocinus (33\%). Metacercariae of C. complanatum were found from $5 \mathrm{Z}$. platypus (16\%) and a C. auratus (12.5\%). Metacercariae of Metagonimus spp. were found only from a Z. platypus (3\%). On the other hand, the 2 species of alien fishes examined from the same region were all negative

Table 1. Infection status with digenetic trematode metacercariae (MC) in fishes from 2 different regions in Chungcheongbuk-do, Korea

\begin{tabular}{|c|c|c|c|c|c|c|}
\hline Locality & Species of fish & $\begin{array}{c}\text { No. } \\
\text { examined }\end{array}$ & $\begin{array}{l}\text { No. (\%) } \\
\text { infected }\end{array}$ & No. (\%) of MC detected & Range & $\mathrm{M} \pm \mathrm{SD}$ \\
\hline \multirow[t]{12}{*}{ Daecheong-ho (lake) } & Native species & & & & & \\
\hline & Zacco platypus & 31 & $28(90)$ & Centrocestus spp. 27 (87) & $7-432$ & $133 \pm 104$ \\
\hline & & & & Clinostomum spp. 5 (16) & $1-15$ & $5 \pm 6$ \\
\hline & & & & Diplostomula 8 (26) & $2-32$ & $10 \pm 10$ \\
\hline & & & & Metagonimus spp. 1 (3) & 32 & 32 \\
\hline & Hemibarbus logirostris & 5 & $5(100)$ & Diplostomula 5 (100) & $1-17$ & $6 \pm 7$ \\
\hline & Carassius auaratus & 8 & $4(50)$ & Clinostomum spp. 1 (12.5) & 3 & 3 \\
\hline & & & & Diplostomula 4 (50) & $3-5$ & $4 \pm 1$ \\
\hline & Pseudogobio esocinus & 3 & $1(33)$ & Diplostomula 1 (33) & 5 & 5 \\
\hline & Alien species & & & & & \\
\hline & Micropterus salmoides & 87 & $0(0)$ & - & - & - \\
\hline & Lapomis macrochirus & 177 & $0(0)$ & - & - & - \\
\hline \multirow{6}{*}{ Musim-cheon (stream) } & Zacco platypus & 18 & $14(78)$ & Exorchis oviformis 9 (50) & 3-107 & $46 \pm 38$ \\
\hline & & & & Metacercaria hasegawai 7 (39) & $2-88$ & $17 \pm 31$ \\
\hline & Alien species & & & & & \\
\hline & Micropterus salmoides & 20 & $0(0)$ & - & - & - \\
\hline & Lapomis macrochirus & 67 & $23(34)$ & Exorchis oviformis 22 (33) & $3-22$ & $8 \pm 5$ \\
\hline & & & & Metacercaria hasegawai 7 (10) & $1-10$ & $6 \pm 3$ \\
\hline
\end{tabular}


for metacercariae infection. Only 2 species of digenetic trematode metacercariae were discovered from fishes obtained from the Musim-cheon. Exorchis oviformis metacercariae and Metacercaria hasegawai were found from Z. platypus ( 9 and 7 fishes, respectively). Bluegills were infected with both trematode species (Fig. 1). The infection status of alien and native fishes in the present study is detailed in Table 1.
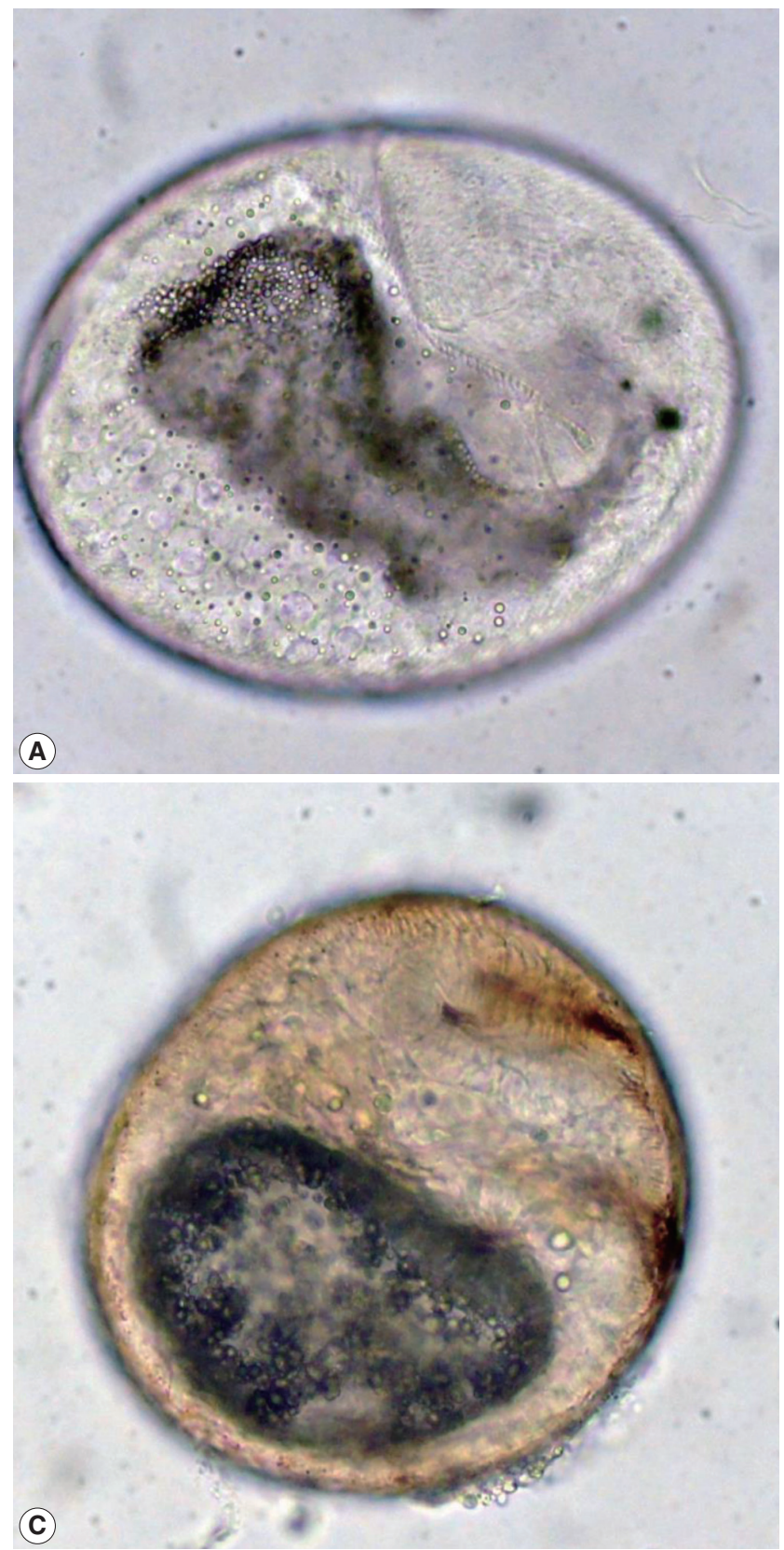

Although the 2 species of alien fishes had been investigated for DTM before, it was sporadic survey which a part of large scaled survey on all kinds of freshwater fish investigation. Sohn et al. [11] examined total 10 M. salmoides and 4 L. macrochirus from Wicheon-stream in Gunwi-gun (gun=county), Gyeongsangbuk-do, and they found total 6 CsMc from 2 largemouth bass. More recently, Yoon et al. [12] investigated 8
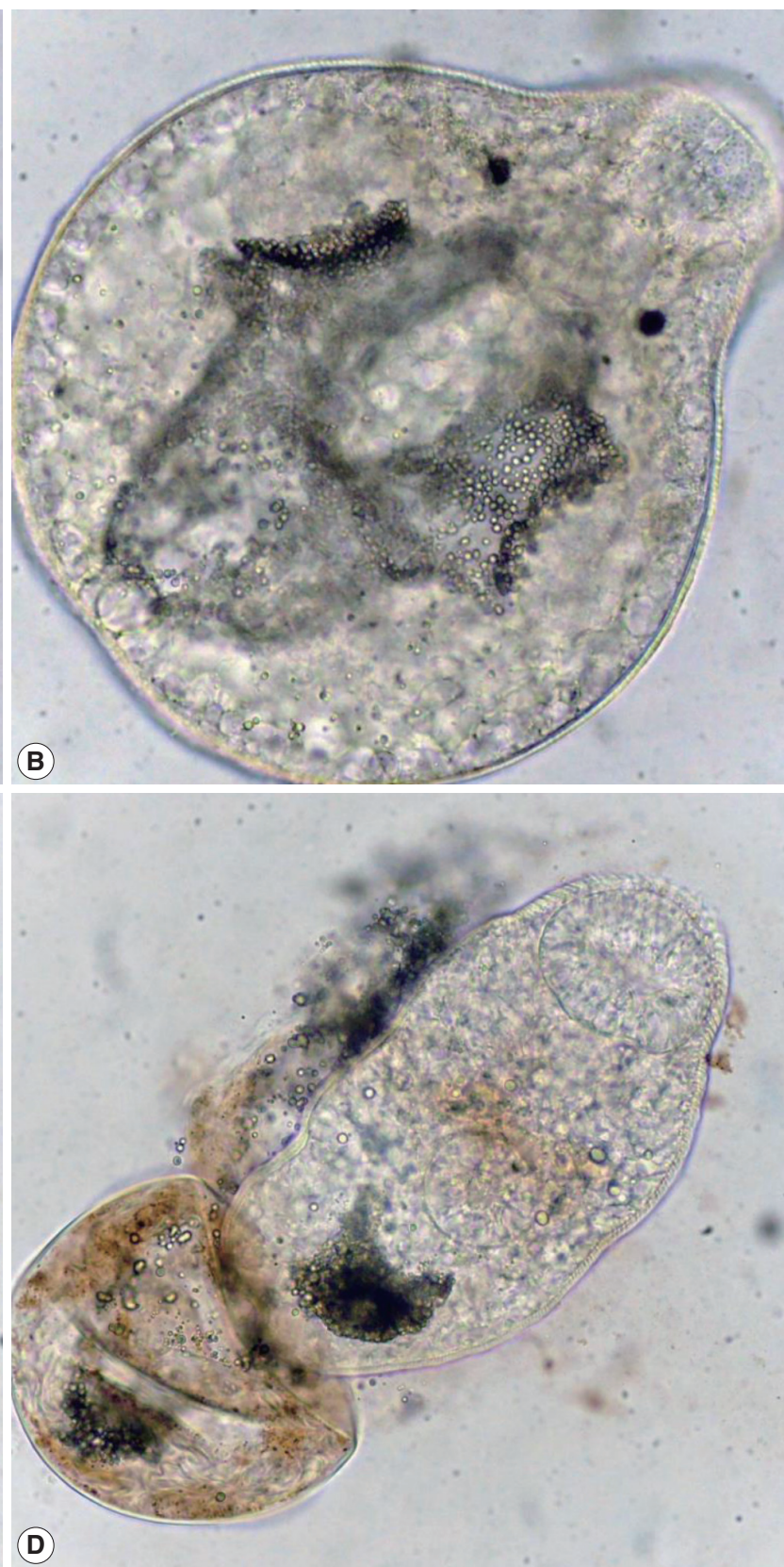

Fig. 1. Exorchis oviformis metacercariae (A, B) and Metacaercaria hasegawai (C, D) collected from the bluegill Lepomis macrochirus. (A, B) Metacercariae of $E$. oviformis which had V-shaped excretory bladder with a pair of eye spots. (C, D) Metacercaria hasegawai, the excretory bladder located in posterior body. (A, C) Encysted larvae. (B, D) Excysted larvae. 
largemouth bass but they didn't find CsMc from the fishes. A bluegill was examined by Sohn et al. [10] from Seomjin-gang, but it was negative for CsMC. In the present study, alien fishes were poorly infected with metazoan parasites compared to native fishes. Although we found over 6 species of metacercariae from native fishes, results for largemouth bass were all negative. Only 2 native parasites in Korea, E. oviformis and Metacercaria hasegawai, were found in the alien species bluegill, with a prevalence of $33 \%$ and $10 \%$, respectively. We did not find any alien helminthes in both native and alien fishes.

Differences in the prevalence of parasitic infection between native and alien populations have been reported for other regions of the world. Dove [16] reported the poor parasitic prevalence of alien freshwater species in eastern Australia, and most of the shared parasitic species originated from native fish species. Lymbery et al. [17] also described the reduced prevalence of parasitic infection in alien species in Australia. This phenomenon is not only limited to freshwater fishes, but is also present in a wide range of alien species including mammals, birds and invertebrates [18-21]. In our case, we observed a poor parasitic infection in alien fishes compared with that of native populations. Even though the numbers of native fish examined were heavily outnumbered by the alien fishes ( 50 vs $351)$, the infection rates were much higher in native fish than in alien fishes (76.5 vs 6.6\%).

Unlike the infection status in the present study, both alien fish species in their original habitat have exhibited parasitic infections with a relatively rich parasitic fauna. Largemouth bass in their native habitat are infected with metazoan parasites belonging to a number of phyla [22-25], and helminth parasites of bluegills have also been investigated [26-28]. It has been known that 2 fish species in their original habitat are infected with several species of digenetic trematode metacercariae including Clinostomum complanatum, C. marginatum, Diplostomum sp., Neascus sp., Posthodiplostomum minimum, strigeids and Uvulifer ambloplitis. However, we did not find any alien parasite species that might be introduced with alien fishes. In fact, we did not find any metazoan parasite species with the exception of an anchor worm species in bluegill (unpublished data).

Lower parasitic prevalence of alien species and an absence of their own parasites may result from several reasons, such as host specificity, life-cycle stages, trophic categories, and methods of introduction [19]. Parasites like trematodes need 2 or more host species to maintain their life-cycle. If the introduced parasites fail to find suitable hosts, they will not survive to successfully invade the ecosystem $[18,19]$. In particular, it may be more difficult to survive for parasites and to find their way as metacercariae in alien fishes. They have to overcome several barriers for a successful invasion. Among the introduced populations, infected fish has to be chosen as a suitable host for successful growth to the adult stage in the host. Although they may overcome the initial progress, they still have to pass the steps concerning adaptation to the environment and the first intermediate hosts.

Consequently, we could not find any helminth parasites from largemouth bass, and only 2 non-zoonotic parasites, $E$. oviformis and Metacercaria hasegawai, were found from bluegills. As with previous studies in other regions of the world, the 2 alien fishes of this study were poorly infected with parasites. However, this study did not cover the whole country and every ecosystem in Korea, and was limited to 2 restricted areas. In addition, we did not find the most important DTM in Korea, C. sinensis, in either native or alien fishes. These results may therefore not ensure the food safety of raw fish consumption in the regions, and thus additional surveys are needed on alien fish populations distributed widely in Korea.

\section{ACKNOWLEDGMENT}

This work was supported by the Health Fellowship Foundation.

\section{CONFLICT OF INTEREST}

The authors declare that they have no conflict of interest with this article.

\section{REFERENCES}

1. Sohn WM. Fish-borne zoonotic trematode metacercariae in the Republic of Korea. Korean J Parasitol 47 (suppl): 103-113.

2. Hong ST, Chai JY, Choi MH, Huh S, Rim HJ, Lee SH. A successful experience of soil-transmitted helminth control in the Republic of Korea. Korean J Parasitol 2006; 44: 177-185.

3. Shin EH, Guk SM, Kim HJ, Lee SH, Chai JY. Trends in parasitic diseases in the Republic of Korea. Trends Parasitol 2008; 24: 143-150.

4. Kim TS, Cho SH, Huh S, Kong Y, Sohn WM, Hwang SS, Chai JY, Lee SH, Park YK, Oh DK, Lee JK. A nationwide survey on the prevalence of intestinal parasitic infections in the Republic of Korea, 2004. Korean J Parasitol 2009; 47: 37-47. 
5. Jeong YI, Shin HE, Lee SE, Cheun HI, Ju JW, Kim JY, Park MY, Cho SH. Prevalence of Clonorchis sinensis infection among residents along 5 major rivers in the Republic of Korea. Korean J Parasitol 2016; 54: 215-219.

6. Kim EM, Kim JL, Choi SY, Kim JW, Kim S, Choi MH, Bae YM, Lee SH, Hong ST. Infection status of freshwater fish with metacercariae of Clonorchis sinensis in Korea. Korean J Parasitol 2008; 46: 247-251.

7. Cho SH, Sohn WM, Na BK, Kim TS, Kong Y, Eom K, Seok WS, Lee T. Prevalence of Clonorchis sinensis metacercariae in freshwater fish from three latitudinal regions of the Korea Peninsula. Korean J Parasitol 2011; 49: 385-398.

8. Cho SH, Lee WJ, Kim TS, Seok WS, Lee T, Jeong K, Na BK, Sohn WM. Prevalence of zoonotic trematode metacercariae in freshwater fish from Gangwon-do, Korea. Korea J Parasitol 2014; 52: 399-412.

9. Sohn WM, Na BK, Cho SH, Lee SW, Choi SB, Seok WS. Trematode metacercariae in freshwater fish from water systems of Hantangang and Imjingang in Republic of Korea. Korean J Parasitol 2015; 53: 289-298.

10. Sohn WM, Na BK, Cho SH, Park MY, Kim CH, Hwang MA, No KW, Yoon KB, Lim HC. Prevalence of Clonorchis sinensis metacercariae in fish from water systems of Seomjin-gang (river). Korean J Parasitol 2017; 305-312.

11. Sohn WM, Na BK, Cho SH, Ju JW, Son DC. Prevalence and intensity of Clonorchis sinensis metacercariae in freshwater fish from Wicheon Stream in Gunwi-gun, Gyeongsangbuk-do, Korea. Korean J Parasitol 2018; 56: 41-48.

12. Yoon KB, Lim HC, Jeon DY, Park S, Cho SH, Ju JW, Shin SS, Na BK, Sohn WM. Infection status with Clonorchis sinensis metacercariae in fish from Tamjin-gang (river) in Jeollanam-do, Republic of Korea. Korean J Parasitol 2018; 56: 183-188.

13. Chyung MK. The Fishes of Korea. Seoul, Korea. Il Ji Sa. 1977, pp 317-336.

14. Byeon HK, Song HB, Jeon SR, Son YM. Feeding habit of Bluegill, Lepomis macrochirus, introduced at lake Paldang. Korean J Limnol 1997; 30: 75-84.

15. Ko MH, Park JY, Lee YJ. Feeding habits of an introduced large mouth bass, Micropterus salmoides (Perciformes; Centrachidae), and its influence on ichthyofauna in the lake Okjeong, Korea. Korean J Ichthyol 2008; 20: 36-44.
16. Dove ADM. Richness patterns in the parasite communities of exotic poeciliid fishes. Parasitol 2000; 609-623.

17. Lymbery AJ, Hassan M, Morgan DL, Beatty SJ, Doupé RG. Parasites of native and exotic freshwater fishes in south-western Australia. J Fish Biol 2010; 76: 1770-1785.

18. Dobson AP, May R. Patterns of invasions by pathogens and parasites. In Mooney HA, Drake JA eds, Ecology and Biological Invasions of North America and Hawaii. Springer-Verlag, Berlin, Germany. 1986, pp 58-76.

19. Torchin ME, Lafferty KD, Kuris AM. Parasites and marine invasions. Parasitol 2002; 126 (suppl): 137-151.

20. Torchin ME, Lafferty KD, Dobson AP, McKenzie VJ, Kuris AM. Introduced species and their missing parasites. Nature 2003; 421: 628-630.

21. Mazzamuto MV, Pisanu B, Romeo C, Ferrari N, Preatoni D, Wauters LA, Chapuis JL, Martinoli A. Poor parasite community of an invasive alien species macroparasites of Pallas's squirrel in Italy. Ann Zool Fennici 2016; 53: 103-112.

22. Sparks AK. Some helminth parasites of the largemouth bass in Texas. Trans Am Microsc Soc 1951; 70: 351-358.

23. Ingham RE, Dronen NO Jr. Endohelminth parasites from largemouth bass, Micropterus salmoides, in Belton and Livingston reservoirs, Central Texas. Proc Helminthol Soc Wash 1980; 47: 140142.

24. Szalai AJ, Dick TA. Proteocephalus ambloplitis and Contracaecum sp. from largemouth bass (Micropterus salmoides) stocked into Boundary Reservoir, Saskatchewan. J Parasitol 1990; 76: 598601.

25. Banks SM, Ashley DC. Observations on the internal helminth parasite fauna of largemouth bass, Micropterus salmoides, from Smithville reservoir, Missouri. J Freshw Ecol 2000; 15: 299-306.

26. Muzzall PM, Peebles CR. Parasites of bluegill, Lepomis macrochirus, from two lakes and a summary of their parasites from Michigan. J Helminthol Soc Wash 1998; 65: 201-204.

27. Wilson S, Camp JW Jr. Helminths of bluegill, Lepomis macrochirus, from a Northern Indiana pond. Comp Parasitol 2003; 70: 88-92.

28. Anderson SM, Fiorillo R, Cook TJ, Lutterschmidt WI. Helminth parasites of two species of Lepomis (Osteichthyes: Centrarchidae) from an urban watershed and their potential use in environmental monitoring. Ga J Sci 2015; 73: 123-135. 
